\title{
Cigarette Expenditure and Its Effect on Human Resource Investment Allocation
}

\author{
Henny Oktavianti ${ }^{1, *}$ Muhammad Umar Burhan ${ }^{2}$, Marlina Ekawati ${ }^{3}$, Nurul \\ Badriah $^{4}$
}

1,2,3,4 University of Brawijaya, Indonesia

${ }^{*}$ Corresponding author. Email: hennyok2020@student.ub.ac.id

\begin{abstract}
This study aims to analyze the expenditure of cigarettes on human resources. Human resource investment is measured using education and health spending. The model is based on an analysis of previous studies that show a bad effect of smoking on health and achievement. Until now, cigarettes still existed and can be consumed freely. However, on the other hand, several studies have shown the bad influence of cigarettes on the quality of human resources. Therefore, the author will discuss the issue of the relationship between cigarette spending and human resources in smokers' households. The authors use IFLS data to estimate the effect of cigarette spending on education spending and health spending. The data used are data from 2007 and 2014. The characteristics of the observed households are the same households in 2007 and 2014. Next, the authors estimate the model using OLS and FIXED. The results show that households with more cigarette spending will reduce spending on education. To find out more, the author makes two models based on the location of residence. More specific results show that household cigarette spending in rural areas will push health spending.
\end{abstract}

Keywords: Expenditure, Cigarette, Education, Health.

\section{INTRODUCTION}

Human resources are human abilities to produce goods and services. These abilities can be in the form of skills. Ability can be improved quality through education. In addition, the quality of human resources is also supported by the quality of health. So, investment in human resources in the form of education and health can be done to maximize the results of human capabilities in the future. An increase in investment implies getting higher returns in the future. At this point, investment in human resources becomes very important.

In this paper, the authors specify the analysis of human resource investment in smoking families. The facts explain that cigarettes are harmful to human health, both for active smokers and passive smokers.

Data shows that deaths caused by smoking reach 21.37 percent of the total male smokers in Indonesia (the 6th largest). If viewed more globally, the human development index in Indonesia is in the sixth position in the ASEAN region in 2018. The HDI figure in 2018 is 7.07 as shown by The tobacco control atlas [1].

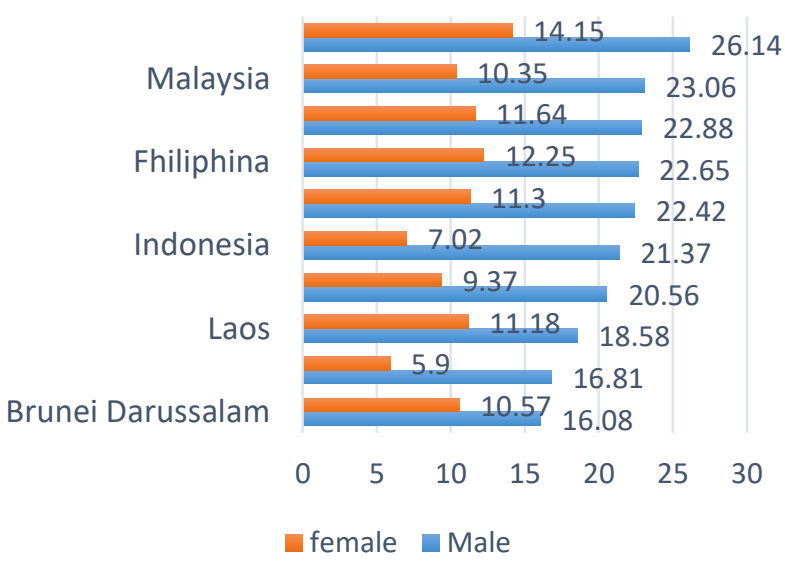

Figure 1. Percentage of Deaths Caused by Smoking in ASEAN Countries in 2016 
Research result Office of the Surgeon General, 2004 in Cotti et al. showed that smoking activity can cause various diseases such as: pharynx, larynx, mouth, esophagus, pancreas, stomach, bladder, kidney, cervix and stomach, stroke, chronic obstructive pulmonary disease, coronary heart disease, asthma, and low birth weight [2].

The next fact is the presence of opiate properties in cigarettes. The content of cigarettes causes someone who smokes for the first time will return to smoking in the next period and continue to repeat. The characteristics of cigarette consumption have special characteristics (typical), have become a special study by experts. As with other commodities in general, the consumer's decision to smoke is determined by considerations of costs and benefits. The basic principle that applies is also the same, namely consumers will continue to smoke if the enjoyment obtained from smoking is higher than the costs of the risks that will be caused, including the health costs of smoking. Consumers are also assumed to be aware that smoking will bring addiction consequences. The existence of addiction will lead to repeated actions, so consumers will tend to repeat their consumption of cigarettes in the future. According to research by Gruber, initiation of smoking begins at age/adolescence. Teenagers as novice smokers may have received quite a lot of information about the dangers of smoking [3]. However, most are still not aware of the negative risks of "addiction" due to smoking.

The facts shown by previous studies and field data point to the negative effect of smoking on health. On the one hand, health is an indicator of the importance of human resources. There is an allegation of a tradeoff between smoking and human resource expenditures. Thus, the analysis of human resource investment in smoking households becomes interesting.

\subsection{Household smokers}

Previous studies' discussion of human resources and cigarettes tended to analyze the physical impact, such as the bad effects of smoking on body health. However, this paper is more directed to the analysis of household expenditures. Smoking households have regular expenditures in the form of cigarettes. Cigarette consumption has been explained will reduce the quality of human resources. So that smoking households are thought to have higher health expenditures and lower education expenditures than non-smoking families.

The author illustrates the allocation of household income of smokers into 4 parts, namely: cigarette expenditure, education expenditure, health expenditure, and other expenses. The pattern of expenditure in the household is influenced by several things, including habits and income levels. The author interprets the habit as a specific repetition (smoking). While the alleged other effects are included in the control variables. According to data from the Central Bureau of Statistics, in Indonesia, spending on food, tobacco and cigarettes occupies the second highest position after food and beverages [4]. The percentage of expenditure per capita for tobacco and cigarettes reaches 12.17 percent of all food expenditure. Meanwhile, if grouped by place of residence in rural and urban areas, the per capita expenditure on tobacco and cigarettes for individuals living in rural areas is higher than in urban areas. In the village, the per capita expenditure on tobacco and cigarettes reached 14.17 percent, while it reached 10.96 percent in the city.

\section{HUMAN RESOURCES INVESTMENT}

Human resources are a key element of the modern economy. According to Becker humans are not just resources but are capital that can generate returns [5]. Any expenditure made as an effort to increase the capital is an investment activity. In the concept of human resource investment, humans are defined as capital that can affect the productivity growth of a nation.

The discussion on this matter tends to the context of human capital (human capital). Human capital is a concept that first appeared in 1776 in classical economics [6]. From a production orientation perspective, Romer in Tariq et al, states that human capital is a fundamental source of economic productivity [7]. Rosen and Gayer had a similar opinion states that human capital is an investment made by humans to increase their productivity [8]. This is also emphasized by Frank \& Bernanke, human capital is a combination of education, experience, training, skills, habits, health, energy and initiatives that affect human productivity [9].

Romer's view is in line with the view of Schultz that human capital is one of the important factors in increasing economic productivity in a country [10]. Human capital can be achieved in two ways. First, humans are used as labor based on their quantitative amount. This states that the more the number of people 
or labor, the higher the productivity. Second, investment is the main way to increase or get human capital. Education and training obtained by humans will increase their abilities and skills, so that productivity will also increase. This second method is no longer concerned with the quantity of the workforce but rather leads to the importance of the qualities that exist in humans.

Todaro revealed that human capital can be measured through education and health [11]. Education and training can be an added value for a human being. This can be explained if the higher a person's education or the more training he has, the higher his abilities and skills. Meanwhile, health is an interrelated field with education. Higher education requires a healthy body to increase productivity. Meanwhile, high education can also affect a person's level of health awareness. Todaro's opinion regarding human capital is still the same as Romer, Schultz and Becker that the quality of human resources will affect productivity. However, Todaro emphasizes human capital indicators that are proxied into education and health.

The allocation of human resources in the context of this research is estimated to be carried out by parents' concern for the quality development of their children. So that investment in human resources is assumed to be carried out since the child is born. Like Todaro's opinion, the allocation of human resource expenditure can be realized in the form of spending on health and education.

\section{EQUATIONS}

The variable used in this study is the expenditure of human resources as the dependent variable. While the expenditure of cigarettes as an independent variable. The author also uses control variables, including: education level, age, gender, income, number of family members.

The data sources are IFLS (The Indonesian Family Life Survey) wave 4 and wave 5 [12][13]. The concept built in this research is based on human capital theory. The author wants to know the influence between variables in a certain period of time ( 7 years). The aim is to find out how the influence of a household's smoking expenditure in 2007 on human resource investment expenditure in 2014. The characteristics of the sample were households that smoked from 2007 to 2014. The number of samples consisted of 319 smoking households.
The data analysis method uses a linear estimation model. The linear model will be used to estimate the predictor variables and the response variables used in the study. Where the data used in the study is discrete and continuous data. One of the predictor variables used is smoking expenditure. Where smoking expenditure is included in food expenditure which when income increases the trend will remain. Therefore, this property is more accurately analysed using Engel's Law approach. This law shows that the proportion of consumer spending on cigarettes increases less than income increases. However, the relationship model between total expenditure (as a proxy for household income) and cigarette spending, in this case is called the Engel curve.

The quadratic model is expressed in the following equation:

$$
Y_{i}=\alpha_{i j}+\alpha_{i j} X_{1}+\alpha_{i j} X_{1}^{2}+\alpha_{i j} X_{2}+\mu_{i j}
$$

The quadratic Engel Curve (QEC) model is intended to accommodate the cigarette expenditure variable, which can increase but in a certain period of time it will decrease again. This assumption is based on the certainty condition of smokers, namely increasing age and decreasing body quality at a certain time. So that spending on smoking does not continue to rise but at a certain point will fall again. In the estimation of the Quadratic Engel Curve (QEC) model, it is linear in the coefficient of the independent variable $(\alpha)$. While the quadratic form is in the independent variable (Xi).

Furthermore, the authors estimate in more detail into two equations. Where the variable of human resource expenditure is divided into two, namely expenditure on education and expenditure on health. To determine the long-term effect, the authors use data from 2014 so that the equation built is as follows:

$$
\begin{gathered}
\text { meduc }_{i}=\alpha_{10}+\alpha_{11} \text { msk }_{i}+\alpha_{12} L s k_{i}^{2}+\alpha_{13} \partial_{i}+\mu_{1 i} \\
\text { mmedic }_{i}=\alpha_{20}+\alpha_{21} m_{s} k_{i}+\alpha_{22} L s k_{i}^{2}+\alpha_{23} \partial_{i} \\
+\mu_{1 i}
\end{gathered}
$$

Where,

meduci = education expenditure in 2014

medic $\quad=$ health expenditure in 2014

mcgrti $\quad=$ cigarette expenditure in 2007

$\partial_{i} \quad=$ control variables

$\alpha_{10}, \alpha_{20} \quad=$ constant

$\alpha_{11}, \alpha_{12}, \alpha_{13}, \alpha_{21}, \alpha_{22}, \alpha_{23}=$ coefficient of independent variable

The first step is to estimate using linear regression models with OLS method and fixed effects. This step 
is used to see the effect of the independent variable on the dependent variable in general. Human resource investment is described into two dependent variables: education and health expenditures. The author looks at cigarette spending on education and health spending separately.

The second step is to conduct a more specific analysis based on the location of the smoking household's residence (rural/urban). This measure is used to see if there is a difference between household smokers in rural and urban areas. This stage is carried out based on data compiled by Central Bureau of Statistics in 2020. The data shows the phenomenon of differences in the pattern of per capita cigarette and tobacco spending in rural and urban areas.

\section{RESULT}

The analysis results show that cigarette spending affects education spending but not health spending. If smoking households increase their cigarette expenditure allocation, then there will be a decrease in spending on education. These results are by the initial assumption that the income spent on cigarettes regularly may increase from time to time in line with the increase in income. It is reinforced by the significant effect of income variables on each model's education and health expenditures.

Furthermore, the cigarette expenditure variable has no effect on health expenditure, possibly because health expenditure will always be allocated incidentally or planned. Households will not care how much they earn for health. If someone is sick, then under any circumstances they still have to pay for medical expenses. Health spending tends not to be deferred. So whatever the income, health expenditures will still be made. So that regardless of health costs will still be allocated by households even though smokers' households also continue to allocate

Table 1. Estimation Result Using OLS and FIXED

\begin{tabular}{|c|c|c|c|c|}
\hline VARIABLES & $\begin{array}{l}\text { meduc } \\
(\mathrm{OLS})\end{array}$ & $\begin{array}{c}\text { medical } \\
(\mathrm{OLS})\end{array}$ & $\begin{array}{c}\text { meduc } \\
\text { (FIXED) }\end{array}$ & $\begin{array}{l}\text { medical } \\
\text { (FIXED) }\end{array}$ \\
\hline \multirow[t]{2}{*}{ smoking } & -0.000393 & 0.0117 & 0.0166 & 0.00926 \\
\hline & $(0.0253)$ & $(0.0134)$ & $(0.0256)$ & $(0.0137)$ \\
\hline \multirow[t]{2}{*}{ smoking $^{2}$} & $3.14 \times 10^{-8 * *}$ & $5.76 \times 10^{-9}$ & $1.86 \times 10^{-8}$ & $4.42 \times 10^{-9}$ \\
\hline & $\left(1.36 \times 10^{-8}\right)$ & $\left(7.43 \times 10^{-9}\right)$ & $\left(1.36 \times 10^{-8}\right)$ & $\left(7.55 \times 10^{-9}\right)$ \\
\hline \multirow[t]{2}{*}{\begin{tabular}{|l|} 
agehead \\
\end{tabular}} & $-3,994 * * *$ & $455.0 * * *$ & $-4,577 * * *$ & $370.6 * *$ \\
\hline & (337.4) & $(175.1)$ & (340.6) & (179.7) \\
\hline \multirow{2}{*}{ femalehead } & $89,695 * * *$ & $-1,941$ & $76,682 * * *$ & $-1,793$ \\
\hline & $(16,687)$ & $(8,682)$ & $(16,610)$ & $(8,777)$ \\
\hline \multirow[t]{2}{*}{ marriedhead } & $135,316^{* * * *}$ & 5,326 & $126.683^{* * * *}$ & 5.566 \\
\hline & $(16,650)$ & $(8,663)$ & $(16,577)$ & $(8,757)$ \\
\hline \multirow[t]{2}{*}{\begin{tabular}{|l|} 
primary \\
\end{tabular}} & $-198,689 * * *$ & $-52,365 * * *$ & $-162,834 * * *$ & $-38,714 * * *$ \\
\hline & $(13,114)$ & $(6,864)$ & $(13,582)$ & $(7,205)$ \\
\hline \multirow[t]{2}{*}{ secondary } & $-127.374 * * *$ & $-35,359 * * *$ & $-121,010 * * *$ & $-27,477 * * *$ \\
\hline & $(16,496)$ & $(8,607)$ & $(16,760)$ & $(8,885)$ \\
\hline \multirow[t]{2}{*}{ tertiary } & -5.822 & -6.801 & $-33,780 * *$ & $-8,420$ \\
\hline & $(14,951)$ & $(7,848)$ & $(15,314)$ & $(8,176)$ \\
\hline \multirow[t]{2}{*}{ lnincome2007 } & $4,855^{* * *}$ & $1,332 * *$ & $3,479 * * *$ & 739.1 \\
\hline & $(1,286)$ & $(670.2)$ & $(1,290)$ & $(683.7)$ \\
\hline \multirow[t]{2}{*}{ hhsize07 } & $57,907 * * *$ & $4,181 * * *$ & $57,246 * * *$ & $3,784 * *$ \\
\hline & $(2.834)$ & $(1,472)$ & $(2,904)$ & $(1,532)$ \\
\hline \multirow[t]{2}{*}{ Constant } & $153,122 * * *$ & $57,106 * * *$ & $200,588 * * *$ & $65,270 * * *$ \\
\hline & $(29.546)$ & $(15,449)$ & $(29,616)$ & $(15,738)$ \\
\hline Observations & 10,678 & 10,394 & 10,678 & 10,394 \\
\hline R-squared & 0.102 & 0.011 & 0.086 & 0.005 \\
\hline Number of EA & & & 319 & 319 \\
\hline
\end{tabular}


Table 2. Estimation Result Based on Location

\begin{tabular}{|c|c|c|c|c|}
\hline VARIABLES & $\begin{array}{l}\text { Meduc } \\
\text { (urban) }\end{array}$ & $\begin{array}{c}\text { educ } \\
\text { (rural) }\end{array}$ & $\begin{array}{c}\text { medical } \\
\text { (urban) }\end{array}$ & $\begin{array}{c}\text { medical } \\
\text { (rural) }\end{array}$ \\
\hline \multirow[t]{2}{*}{ smoking } & -0.00325 & -0.00103 & 0.0228 & -0.00269 \\
\hline & $(0.0425)$ & $(0.0311)$ & $(0.0216)$ & $(0.0177)$ \\
\hline \multirow[t]{2}{*}{ smoking2 } & $2.07 \times 10^{-8}$ & $3.01 \times 10^{-8}$ & $-3.06 \times 10^{-9}$ & $2.13 \times 10^{-8 *}$ \\
\hline & $\left(2.00 \times 10^{-8}\right)$ & $\left(2.02 \times 10^{-8}\right)$ & $\left(1.07 \times 10^{-8}\right)$ & $\left(1.16 \times 10^{-8}\right)$ \\
\hline \multirow[t]{2}{*}{ agehead } & $-4,770 * * *$ & $-3,159 * * *$ & $711.0 * *$ & $404.9 * *$ \\
\hline & $(654.2)$ & (358.4) & $(328.3)$ & (202.8) \\
\hline \multirow[t]{2}{*}{ femalehead } & $147,655^{* * *}$ & $56,943 * * *$ & 57.03 & $-1,874$ \\
\hline & $(32.187)$ & $(17,589)$ & $(16,249)$ & $(9,950)$ \\
\hline \multirow[t]{2}{*}{ marriedhead } & $212,442 * * *$ & $83,676 * * *$ & 3,890 & 6,772 \\
\hline & $(32,018)$ & $(17,562)$ & $(16,149)$ & $(9,950)$ \\
\hline \multirow[t]{2}{*}{ primary } & $-301,544 * * *$ & $-82.511 * * *$ & $-80,719 * * *$ & $-25,204 * * *$ \\
\hline & $(24,717)$ & $(14,247)$ & $(12,506)$ & $(8,121)$ \\
\hline \multirow[t]{2}{*}{ secondary } & $-220,015 * * *$ & $-29,113$ & $-64,745 * * *$ & $-8,999$ \\
\hline & $(29,124)$ & $(18,704)$ & $(14,706)$ & $(10,626)$ \\
\hline \multirow[t]{2}{*}{ tertiary } & $-121,196 * * *$ & $81.173 * * *$ & $-41,526 * * *$ & $22,435 * *$ \\
\hline & $(24,907)$ & $(17,939)$ & $(12,673)$ & $(10,241)$ \\
\hline \multirow[t]{2}{*}{ lnincome2007 } & $5,064 * *$ & $2,422 *$ & $2,836 * *$ & 104.1 \\
\hline & $(2,300)$ & $(1,431)$ & $(1,162)$ & $(812.2)$ \\
\hline \multirow[t]{2}{*}{ hhsize07 } & $68,992 * * *$ & $47,545 * * *$ & 2,823 & $4,694 * * *$ \\
\hline & $(5,178)$ & $(3,093)$ & $(2,589)$ & $(1,752)$ \\
\hline \multirow[t]{2}{*}{ Constant } & $209.981 * * *$ & $107,908 * * *$ & $65,378 * *$ & $43,787 * *$ \\
\hline & $(56,303)$ & $(31,352)$ & $(28,661)$ & $(17,807)$ \\
\hline Observations & 4,431 & 5,896 & 4,294 & 5,760 \\
\hline R-squared & 0.107 & 0.093 & 0.013 & 0.010 \\
\hline
\end{tabular}

expenditures for cigarettes. This situation may have an impact on the welfare of the smoker's family when they are sick. However, this is not the focus of this research.

In the next analysis, the authors estimate based on the location of residence. This discussion stage is important because of the general finding that income affects each model in the previous analysis. One idea to see if there is a significant difference in the income control variable is to use an analysis approach based on the location of residence. Rural and urban residence locations have different characteristics. The differences in these characteristics can be income variable, type of work, level of education and smoking habits. The estimation results show that cigarette spending has an effect on health spending in rural areas. Writer will discuss one by one starting from the location of residence in urban areas. Cigarette spending has no effect on health and education spending. Characteristically, urban households have a better level of education. This status may affect the way the city dwellers think that education and health are very important. So that whatever their spending on smoking will not affect the allocation of education and health expenditures. Meanwhile, in rural areas, awareness of the importance of health and education is lower than in urban areas. Thus, smoking households in rural areas will reduce their health expenditures if they increase their cigarette consumption or vice versa.

Furthermore, why household smokers in rural areas tend to ignore the cost of education. The possibilities that may occur in the field are that the cost of routine education (called SPP in Indonesia) cannot be postponed. So it must be allocated every month. A second possibility is that there are many free or lowcost schools in rural areas. The third possibility is that people in rural areas only rely on standard formal education without adding other skills. So that no matter how much cigarette spending will affect education spending in rural areas. 


\section{AUTHORS' CONTRIBUTIONS}

Research related to human capital has been discussed in previous studies. However In this paper, the author focuses more on the proportion of household expenditures. Furthermore, the researchers specify on smoking households. It is suspected that smoking households have unique spending patterns related to human resources. The uniqueness lies in the inconsistent mechanism of household expenditure allocation. The inconsistency lies in the decision to allocate revenue. On the one hand they spend their income to improve the quality of human resources, but on the other hand they spend their income to reduce the quality of human resources through cigarette consumption. Therefore, the author's contribution is to provide an empirical illustration related to these findings.

The results showed that cigarette spending will reduce the allocation of education. However, the amount of spending on cigarettes has no effect on health spending. This finding suggests that health spending should be allocated under any circumstances. Health spending cannot be deferred like education spending. Families of active smokers with small or poor incomes will be more desperate when they are sick. During the COVID-19 pandemic, health spending will increase. Both expenses for maintaining health and for treatment. This condition will be faced by every individual and family, including smokers' families. The main thing that needs to be considered, especially in poor smoking families, is to reduce smoking expenditure, so that the risk of declining health quality will be reduced. Awareness of health risks needs to be increased during the COVID-19 pandemic, if smoking families want spending on health to be more efficient.

\section{ACKNOWLEDGMENTS}

We would like to thank the previous researchers who have inspired the authors to develop this research. We also thank the promoter team. This paper was prepared in order to support the main research which is in the working paper stage under the guidance of the promoter team. Thanks are also conveyed to the internal team who assisted in technical matters, so that this paper can be submitted to the public.

\section{REFERENCES}

[1] The tobacco control atlas, J. Drope and N.W. Schluger, Ed., $6^{\text {th }}$ ed. Atlanta: American Cancer Society and Vital Strategies. 2018.

[2] C. Cotti, E. Nesson and N. Tefft, The Effects of Tobacco Control Policies on Tobacco Products, Tar, and Nicotine Purchases among Adults: Evidence from Household Panel Data. American Economic Journal: Economic Policy, vol. 8, no.4, pp.103-23, Nov. 2016, DOI: https://doi.org/.10.1257/pol.2015026

[3] J. Gruber and S. Mullainathan. Do cigarette taxes make smokers happier?, NBER Working Paper, no. 8872, Apr. 2002, DOI: 10.3386/w8872. [Online]. Available: http://www.nber.org/papers/w8872

[4] Rata-rata Pengeluaran Per Kapita Sebulan Menurut Kelompok Barang: 1999, 2002 to 2019, Central Bureau Statistics Indonesia, Nov. 2021. [Online].

Available: https://www.bps.go.id/subject/5/konsumsi-danpengeluaran.html\#subjekViewTab3

[5] G.S. Becker, Human Capital: a Theoretical and Empirical Analysis, with special reference to education, 3rd ed. London: The University of Chicago Press, Ltd. 1993.

[6] P. Fitzsimons, Human Capital theory and education, The Encyclopedia of education. London: Macmillan, 1999.

[7] M. Tahir, A. Hayat, K. Rashid, M.A. Afridi and Y.B. Tariq, Human capital and economic growth in OECD countries: some new insights, Journal of Economic and Administrative Sciences, vol. 36, no. 4, pp. 367380, Oct. 2020. DOI: https://doi.org/10.1108/JEAS-07-20190073

[8] H.S. Rosen and T. Gayer, Public finance, $8^{\text {th }}$ ed. New York: McGraw-Hill. 2008.

[9] R.H. Frank and B. Bernanke, Principle of macroeconomics, McGraw-Hill/Irwin, 2007, ISBN 0071108203, 9780071108201.

[10] T.W. Schultz, Investment in human capital, American Economic Review, vol. 51, no.1, Mar. pp. 1-17. 1961, [Online]. Available: https://www.jstor.org/stable/1818907 
[11] P. M. Todaro, Pembangunan Ekonomi Dunia Ketiga," $1^{\text {st }}$ ed. Jakarta: Penerbit Erlangga. 2000.

[12] The Indonesian Family Life Survey (IFLS) wave 4. RAND: Social and economic well-being, May. 2008. [Online]. Available: https://www.rand.org/well-being/social-andbehavioral-policy/data/FLS/IFLS/ifls4.html
[13] The Indonesian Family Life Survey (IFLS) wave 5. RAND: Social and economic well-being, Aug. 2015. [Online]. Available: https://www.rand.org/well-being/social-andbehavioral-policy/data/FLS/IFLS/ifls5.html 